\title{
Geochemical connection between the Granitic plutons and the rhyolitic volcanics: A case of the Cretaceous granitic magmatism in the central Sulu orogen, eastern China
}

\author{
TENGFEI ZHOU ${ }^{1 *}$, YAOQI ZHOU ${ }^{*}$, ZHENKAI ZHANG ${ }^{2}$, HUI
} ZHANG $^{1}$

${ }^{1}$ Department of Geology, School of Geosciences, China University of Petroleum, Qingdao, 266580, P.R.China

${ }^{2}$ Shaanxi Center of Mineral Geological Survey, Shaanxi Institute of Geological Survey, Xi'an, 710054, P.R.China

There was a early Cretaceous felsic LIPs developed in the central Sulu orogen. It contains multi-stage granitic pluton and andesitic-dacitic-rhyolitic volcanism. The crystal-poor rhyolitic ignimbrite in Lingshan island has been proved not to be derived from the intermediate igneous rock. This research focues on constructing the geochemical connection between the eruptive rhyolite and the plutonic granite.

The granitic pluton is a suit of I-A type association represented by alkali granite (A-type) and syengranite (I-type). The Zircon $\mathrm{U}-\mathrm{Pb}$ dating results give the ages of the rhyolite, the A-type granite and the I-type granite are $121.6 \pm 1.3 \mathrm{Ma}$, $120.7 \pm 1.8 \mathrm{Ma}$ and $116.8 \pm 1.1 \mathrm{Ma}$ respectively. The I-type and the rhyolites show similar geochemical characteristics with extremely high $\mathrm{SiO}_{2}(75 \sim 79 \%)$, low $\mathrm{MgO}$ content $(0.1 \sim 0.2 \%)$ and strong Eu anomaly (0.3 0.4), but the I-type ones have lower REEs contents. These suggest the rhyolite is not derived from the I-type granite although the rhyolites are ploted in I\&S\&M area in the $\mathrm{X}-1000 \mathrm{Ga} / \mathrm{Al}$ diagrams. The rhyolite is likely formed by removing mineral assemblages of $(0.77 \mathrm{Fsp}+0.125 \mathrm{Plag}+0.05 \mathrm{Bt}+0.033 \mathrm{Am}+0.006 \mathrm{Ap}+$ $0.025 \mathrm{Mag}$ ) through $35 \%-45 \%$ fractional crystallization, from the A-type granite (the relatively parental magma with $\mathrm{SiO}_{2}$ $69 \sim 74 \%$ ). The relatively depleted in some incompatible elements related to minerals of the rhyolites than the granites (Sr rhyolite $/ \mathrm{Sr}_{\text {Atype }} \approx 0.7$, Barhyolite/BaAtype $\approx 0.5$, Ce$_{\text {rhyolite }} / \mathrm{Ce}_{\text {Atype }} \approx 0.3$ ) also prove that the fractional crystallization occurred during the extraction of the High- $\mathrm{SiO}_{2}$ rhyolitic melt from the A-type granitic crystal mushes underlying. The intermediate enclaves $\left(\mathrm{SiO}_{2} 59 \%, \mathrm{FeOt} 5.6 \%, \mathrm{MgO} 2.32 \%\right)$ in the I-type granite indicate the magma mixing during its formation. It was caused by a magma mixing event between the felsic magma and a latter basic recharging magma, and then underwent highly fractionated crystallization processes.

The evolution of the granitic magmatism not only uncovers the inner relationships but also implies the rootdelamination and the asthenosphere upwelling at $\approx 120 \mathrm{Ma}$. 